\title{
Challenging climate
}

\author{
Keeping global temperature to no more than $1.5^{\circ} \mathrm{C}$ above pre-industrial levels is an enormous task that requires the \\ complementary efforts of scientists from across the biological, physical and social sciences.
}

T he latest Intergovernmental Panel on Climate Change (IPCC) report on what life would be like in a world that is $1.5^{\circ} \mathrm{C}$ warmer than in the nineteenth century makes both depressing and inspiring reading. The task is enormous, but the detail in which it is now understood means that policy measures needed to achieve that goal can be immediately implemented, if the will is there. The report covers all aspects of the difference between a world $1.5^{\circ} \mathrm{C}$ or $2^{\circ} \mathrm{C}$ warmer, including both causes and consequences of change in physical, biological and social systems. A key point is that these cannot be fully disentangled from each other. However, it still remains useful to consider the report from a biological point of view, especially when news coverage often focuses on physical and social impacts and policy options, with mention of only a few high-profile ecological consequences.

The October 2018 IPCC report reveals that in a $2{ }^{\circ} \mathrm{C}$ world, $18 \%$ of insects, $16 \%$ of plants and $8 \%$ of vertebrates are expected to lose at least half of their geographic range, based on analysis of the 105,000 species that have been studied so far. However, these figures could be reduced to $6 \%, 8 \%$ and $4 \%$, respectively, if warming could be kept below $1.5^{\circ} \mathrm{C}$. Warm water coral reefs are expected to decline in extent by $70-90 \%$ in a $1.5^{\circ} \mathrm{C}$ world, compared with over $99 \%$ in a $2{ }^{\circ} \mathrm{C}$ world, and the proportion of terrestrial ecosystems expected to shift to an alternative state is $4 \%$ at $1.5^{\circ} \mathrm{C}$ versus $13 \%$ at $2{ }^{\circ} \mathrm{C}$.

However, the report does not just talk about $1.5^{\circ} \mathrm{C}$ and $2{ }^{\circ} \mathrm{C}$ end points, but also about the different paths to reach them. The key issue is that of overshoot: whether $1.5^{\circ} \mathrm{C}$ of warming is reached with or without a transient period of even greater warming. For some physical systems, this may not make a significant difference. For example, irreversibility is not expected in the extent of Arctic ice cover, so the once-in-a-century ice-free year expected at $1.5^{\circ} \mathrm{C}$ (compared with once-in-a-decade at $2{ }^{\circ} \mathrm{C}$ ) applies regardless of whether it is reached after a period of greater melting.
By contrast, for most biological systems, the path to a $1.5^{\circ} \mathrm{C}$ world matters an awful lot. Species extinctions, from which there is no return, are the most extreme example of this, but biological systems at many levels are likely to experience tipping points that are hard to reverse. These could range from shifts between ecosystem types, to loss of permafrost carbon, to changes in the microbiomes of individual organisms.

Anthropogenic ecosystems will also be affected in substantial ways and are a key part of both mitigation and adaptation strategies. Yields of marine aquaculture and fisheries are likely to be reduced more in a $2{ }^{\circ} \mathrm{C}$ world than in a $1.5^{\circ} \mathrm{C}$ one, yet both have a role to play in food security, especially as an alternative source of protein in response to changes in terrestrial agriculture. Land for terrestrial agriculture is likely to come under increased competition from the land use demands of both bioenergy and afforestation, and given the complexity of biological and ecological systems highlighted in the IPCC report, it is often easy to feel pulled in contradictory directions. An understanding of ecology has the potential to reduce some of this conflict, for example by focusing carbon dioxide removal projects on the restoration of appropriate natural habitats and healthy soils for carbon sequestration.

Resolving competing land use priorities and balancing negative and positive feedbacks can be daunting. For example, the study by Thaker et al. in this issue adds to the known effect of wind turbines on birds by showing that the reduction in the presence of avian predators can affect population density, behaviour and physiology of reptile prey. This should certainly not be seen as a reason to avoid wind energy, but it illustrates the fact that all energy choices have ecological consequences, which must be factored into the choice of site for renewable energy sources. Of course, reducing total energy use should be an equal global priority alongside cleaning up the energy supply.
A more extreme example of the fact that technological fixes can have complex repercussions is the recent study by Trisos et al., which suggests that solar geoengineering attempts, and specifically the way in which they are terminated, could have severe consequences for biodiversity.

Also in this issue, Doughty et al. report that increasing temperature may lead to a darkening of tropical forest leaves, thereby increasing the energy absorbed from the sun and potentially exacerbating the warming effect. Again, this needs to be considered in context as there are many climate feedbacks between physical and biological systems that are challenging to consider simultaneously in models, meaning that individual feedbacks should not be given undue prominence at the expense of the others.

Despite these complexities, the IPCC report's message for biological scientists is clear: there is still the chance to keep warming to a level that falls short of catastrophic, and our disciplines are absolutely central to the task. We should seek to understand how different scenarios and policies might trade off against each other, but we should not fall into the trap of letting these uncertainties hinder progress. Nor should we waste time squabbling over which aspects of the environmental challenge are the most important. For example, habitat loss is currently the major driver of species extinctions, but it is clear that climate change will soon become similarly important. Moreover, given the links between habitat loss, deforestation, carbon storage, food security and economic policy, it is unrealistic to talk about any driver in isolation. The IPCC report presents a stark depiction of the massive difference between the effects of $1.5^{\circ} \mathrm{C}$ and $2{ }^{\circ} \mathrm{C}$ warning, and should be treated as a multilateral call to arms for all climate and related environmental research and policy.

Published online: 22 November 2018 https://doi.org/10.1038/s41559-018-0748-3 